\title{
Policy Study of the Authorities Hegemony on 2013 Curriculum in Southeast Sulawesi
}

\author{
Andi Muhammad Ali ${ }^{*}$, Azaz Akbar ${ }^{1}$, Madi $^{2}$ \\ ${ }^{1}$ Faculty of Teacher Training and Education, Universitas Muhammadiyah Buton, Baubau 93721, Indonesia \\ ${ }^{2}$ Faculty of Islamic Religion, Universitas Muhammadiyah Buton, Baubau 93721, Indonesia \\ *Corresponding author. Email: andiali649@gmail.com
}

\begin{abstract}
Domination Excessive power will always lead education away from the needs of the people and national culture. Excessive power also changes the direction of education from liberation to stunt. For example, the 2013 curriculum which aims to create people of faith and character has not been able to be realized. In the authors view, the 2013 curriculum is driven by the needs of certain parties. One of the UNs sustainable development agendas is to build quality education, so that the maximum and effective realization of the 2013 curriculum is able to realize the development agenda for the benefit of humans and planet earth. This study aims to reconstruct the implementation of policies that are already running. The research method is descriptive qualitative with case studies. The results showed that first the teaching and learning process was intimidated by the practice of nepotism, secondly the educational output was only used as a tool to benefit the owners of capital. Based on the results, it can be concluded that the implementation of the 2013 curriculum in Southeast Sulawesi has not yet led to the expected goals.
\end{abstract}

Keywords: policy, curriculum 2013, hegemony

\section{INTRODUCTION}

The goal of Environmental education is for students to have rational knowledge, attitudes and behaviour and be responsible for population and environmental problem. The 2013 curriculum has four aspects of assessment, namely aspects of knowledge, aspects of skills, aspects of attitude, and behaviour. In the 2013 curriculum, especially in learning materials there are streamlined material and added material. The streamlined material is seen in Indonesian, Social Studies, PPKn, etc., while the material added is Mathematics. Strengthening aspects of attitudes and behaviours in this curriculum aims to restore the nation's character values that are increasingly disappearing. The fact is that in our country immoral practices often occur in people from ordinary groups to state officials.

Curriculum k.13 is a new curriculum implemented by the government which aims to replace the Education Unit Level Curriculum. The 2013 curriculum is on probation in 2013 by involving several schools to become a trial school. The 2013 curriculum was first implemented since 2013 but until now there are still pros and cons in implementing it. Even the implementation of this curriculum is still being reviewed and evaluated. Pros and cons that occur due to new things in the learning process so that some teachers are not accustomed to teaching it, plus the teacher's obligation to complete the learning tools that can be said very much. Substitution of the old curriculum into the curriculum has a major influence on the regulation of local government policies in terms of economic, political and cultural. The amount of costs incurred by the government to revise the curriculum and distribute it to the regions invited certain elements to be able to obtain assets. A small example that occurred in the field was the misappropriation of school operational assistance funds to support the completion of 2013 curriculum books.

Since the start of the industrial era in Europe, the idea of globalization has emerged that has made the boundaries of all countries disappear. This new culture of globalization opens the world to influence each other in the fields of ideology, politics, culture, economics. The more advanced a country's civilization and technology, the stronger its influence. Hegemony is a form of mastery over a certain group that uses consensus leadership and intellectual dominance. The domination of power today no longer talks about politics but also enters the world of education. In general, the foundation of education includes the pattern of educational social activities. Namely transactional patterns, nomothetic (dimensions of behaviour that are normative) and idiographic patterns. The fact shows the rampant abuse of power and the education budget carried out both from the school to the relevant offices such as positions in the education office and schools dominated by families and relatives of officials, misappropriation of school operational assistance funds and the use of certification funds that are not suitable to support professionalism teacher. Departing from this conception it is necessary to conduct a review of hegemony in the world of education. the purpose of this study was to determine the pattern of educational hegemony that occurred specifically in the Southeast Sulawesi Province

\section{LITERATURE REVIEW}

The curriculum is the foundation in achieving learning objectives, the better the curriculum design the better the 
quality of education that will be produced. Therefore, a revision of the curriculum is needed to adjust to the conditions that are happening now. Curriculum changes are needed all the time because the curriculum will always respond to developments in life, both technological, cultural and political life. The latest change in the education curriculum in our country is the 2013 curriculum. The 2013 curriculum or character education curriculum is a curriculum that was born out of government and community concerns about the poor quality of human resources, especially in terms of values, morals and ethics. Indications that can be seen are acts of corruption and nepotism that occur among ordinary people to state officials, violent behaviour that occurs every day in society, and other events that damage the moral order of society. "The 2013 curriculum demands that in the implementation of learning students are given the freedom of thinking to understand problems, develop problem solving strategies, propose ideas freely and openly. The teacher's activity in learning is to train and guide students to think critically and creatively in solving problems" [1].

Hegemony is a form of mastery over certain groups by using consensus intellectual and moral leadership. According to political expert Antonio Gramsci developed the initial meaning to refer to the dominance of a social class over other social classes in society. "Hegemony is considered as a central and original idea developed by Gramsci. The Hegemony theory is seen as having brought about major changes and has led to a debate over the theories of social change, especially for those who want radical and revolutionary change. Gramsci's concepts of thought about hegemony, civil society, political society, counter hegemony, war of position, war of movement, organic intellectual and its role in social transformation, are ideas that are considered brilliant, and make important contributions to the development of theories social, and foster critical political awareness "[2].

Hegemony is not only applied to the politics of state power but education in it. Elementary schools up to senior high school level are still dominated by the interests of capital owner's orientation, namely students are taught and directed to become workers in the company or in offices after they finish school. The hegemony of humanitarianism in social science lessons from elementary to high school. This can be known from several factors, which are related to the past history of social studies which are thick with political nuances and indoctrination, the application of social studies learning models that are rigid, monotonous, homogeneous, and the superiority of teachers who consider themselves to be active subjects on one side, while placing students as static objects [3].

The 2013 curriculum change policy is based on internal and external challenges faced by the Indonesian people in order to prepare a productive, creative, innovative and affective generation [4], the four expected aspects of the 2013 curriculum were not implemented effectively in schools. Schools dominate the affective inculcation of value to students and ignore the rapid changes in productive technology. This has become reasonable because the government has not maximally provided supporting facilities such as fast internet networks in eastern Indonesia. "Until 2013 there were 71.19 million internet users in
Indonesia. With this amount, internet penetration in Indonesia in 2013 was $28 \%$. Although lift penetration has continued to increase, internet users in Indonesia are not geographically distributed. The most internet users in Indonesia are in Western Indonesia" [5].

The 2013 curriculum-based education system will certainly be realized according to the target if every element of the department and school leadership is responsible for the mandate given. "The concept of learning leadership strategies to welcome the implementation of the 2013 curriculum includes four categories, exemplary, classroom and out-of-class learning, school culture, and reinforcement" [6]. the facts that occur especially in schools and related education agencies have not been maximized in the management of leadership. "The instructional leadership of school principals is recommended to be one of the solutions for the effectiveness of the implementation of the 2013 curriculum. Instructional leadership is the leadership of school principals who prioritize teaching and learning in their leadership. Principals who are in favour of academics, instructional leadership are believed to be able to solve the problems of implementing the 2013 curriculum. Prioritizing the principal's involvement in orientation and training in implementing the 2013 curriculum is recommended" [7].

There is a relationship between the ruling regime to conduct hegemony in the world of education with historical content in the history text book [8]. the spirit of the era controlled by the authorities influences the content of history, namely the attitude of prioritizing the interests of groups in the world of education that is used to perpetuate capital owners in the history curriculum in 1975, the KBK curriculum, until the 2013 curriculum. The Ministry of Education and Culture which consists of four themes contains character values contained in the book. In the teacher's handbook and the student handbook in each theme contains a variable amount of character values and uneven distribution, the character values presented are mostly in accordance with indicators KI 1 and KI 2, but also found characters outside these indicators" [9]. The pictures in the 2013 curriculum textbooks in elementary schools especially social science books on the theme of work show illustrations of professions working in the office and on the theme of "ideals" provide an illustration of the great profession as an employee in the office. This certainly turns off the imagination of students to be able to create and create their own jobs. In addition, the hegemony in textbooks also clarifies religious teachings. As quoted in the Java post (Radar Kudus) The compulsory elementary book / elementary school curriculum in 2013 there is a controversial sentence that is on the theme "events in life" there is a narrative that directs to the radical concept of religion. In this case denying understanding which is not in line with the politics of the authorities.

Bourdieu use the concept of symbolic power as the power to construct reality, a power that is not seen when others do not know that they are actually being influenced and are subject to certain powers. symbolic violence that occurred at a favourite school. When students from poor families are given the opportunity to go to a school where the majority of students come from the upper classes, lower class students will get to know a lot of upper-class habitus. This 
[7] Anon 2014 Problematika Kurikulum 2013 Dan Kepemimpinan Instruksional Kepala Sekolah

[8] Marlina 2016 Pengaruh Zeitgeist Terhadap Muatan Sejarah di Buku Teks Pelajaran Sejarah SMA Kurikulum 1975-2004 Indones. J. Hist. Educ.

This type of research is a descriptive study with a qualitative approach. Descriptive research aims to describe, painting systematically, factually and accurately about the facts, the nature of the relationship between the phenomena under investigation. The qualitative method is where it is endeavoured to find a description and explanation of the problem discussed. [11]

The purpose of this study was to determine the Hegemony of Power in Southeast Sulawesi Education. This research was conducted in the city of Baubau with area sampling techniques and study of library materials that are relevant to this research study.

\section{CONCLUSION}

Based on the results of these studies describe the 2013 curriculum education policy $(\mathrm{K}-13)$ as a development program for Education Unit Level Curriculum still a bridge that connects education with the authorities. The availability of textbooks that show a mindset that is more beneficial to certain groups is still found in 2013 curriculum teaching materials. Regional autonomy also takes part in influencing the hegemony of power. The study found that there were some components of the qualification indicators for school principal appointment being eroded due to proximity to regional leaders which had the potential to reduce the idealism of the regional head's policy.

\section{REFERENCES}

[1] Sinambela P N J M 2013 Kurikulum 2013 dan Implementasinya dalam Pembelajaran e-journal Univ. Negeri Medan

[2] Siswati E 2018 Anatomi Teori Hegemoni Antonio Gramsci Translitera J. Kaji. Komun. dan Stud. Media

[3] Zulkarnain I 2013 Pendidikan Indonesia: Dari Hegemoni dan Kuasa Pengetahuan ke Pendangkalan Kemanusiaan Society

[4] Machali I 1970 Kebijakan Perubahan Kurikulum 2013 dalam Menyongsong Indonesia Emas Tahun 2045

J. Pendidik. Islam

[5] Asosiasi Penyelenggara Jasa Internet Indonesia APJII 2014 Profil Pengguna Internet Indonesia 2014

[6] Usman H and Eko Raharjo N 2013 Strategi Kepemimpinan Pembelajaran Menyongsong Implementasi Kurikulum 2013 J. Cakrawala Pendidik.
[9] Mumpuni A and Masruri M S 2016 Muatan NilaiNilai Karakter Pada Buku Teks Kurikulum 2013 Pegangan Guru Dan Pegangan Siswa Kelas II J. Pendidik. Karakter

[10] Martono N 2019 Sekolah Inklusi Sebagai Arena Kekerasan Simbolik Sosiohumaniora

[11] P.D S 2014 Metode penelitian pendidikan pendekatan kuantitatif.pdf 